\title{
Comparison of left atrial pressure and wedge pulmonary capillary pressure Pressure gradients between left atrium and left ventricle
}

\author{
David Verel and Norman H. Stentiford \\ From The Cardio-Thoracic Unit, Northern General Hospital, Sheffield
}

Simultaneous records of wedged pulmonary capillary pressure and left atrial pressure have been made in 12 patients. The pressure changes in the left atrium preceded those in the pulmonary capillary bed by 0.06 to $0.14 \mathrm{sec}$.

This delay, together with the damping of the wedged pulmonary capillary pressure, may result in a false appearance of an end-diastolic gradient between the left atrium and the left ventricle if simultaneous wedged pulmonary capillary pressure and left ventricular tracings are compared.

In severe aortic valve incompetence the reflux of blood into the left ventricle from the aorta during ventricular diastole may be so profuse that the pressures in the left ventricle and aorta equalize before the end of diastole. In these circumstances the end-diastolic ventricular pressure may exceed the left atrial pressure, so that the mitral valve is prematurely closed by the rise in ventricular pressure (Wright, Toscano-Barboza, and Brandenburg, 1956; Colvez et al., 1959). In some cases this premature closure is preceded by regurgitation of blood into the left atrium shown by left ventricular angiocardiography. This phenomenon is likely to account for some, if not all, cases of Austin Flint murmur (Wigle and Labrosse, 1965 ; Lochaya, Igarashi, and Shaffer, 1967).

Premature mitral valve closure may also be seen in lesser degrees of aortic incompetence where the aortic and ventricular end-diastolic pressures have not equalized, either as a result of a change in the atrioventricular rhythm (Colvez et al., 1959), or because the end-diastolic pressure, while not reaching aortic diastolic levels, exceeds the atrial pressure (Wigle and Labrosse, 1965). A similar phenomenon has been shown in dogs (Welch, Braunwald, and Sarnoff, 1957). Since the occurrence of premature mitral valve closure may be regarded as evidence of a significant milestone in the decline of Received 3 June 1969. left heart function in aortic incompetence, measurements of left atrial and ventricular pressure are of considerable importance.

Most of the studies discussed above were made by direct pressure measurements from the left atrium, left ventricle, and aorta. In man, this involves a difficult catheterization technique in patients whose clinical condition may be poor. The recording of wedged pulmonary capillary pressure provides a much safer way of assessing the left atrial pressure, and, indirectly, the ventricular end-diastolic gradient. Both Oliver, Gazetopoulos, and Deuchar (1967) and Lochaya et al. (1967) have shown reversed gradients across the mitral valve by this technique in patients with aortic regurgitation.

Transseptal left atrial catheterization has been in routine use in this unit for mitral and aortic valve assessment for several years (Verel and Taylor, 1967). The prospect of using the less risky wedge pressure measurements prompted a comparison of the techniques using simultaneous measurements of wedged pulmonary capillary pressure and left atrial pressure.

\section{Subjects and methods}

The results obtained in 12 patients are reported in this paper. In Cases $\mathrm{I}-4$ the valve lesions were confined to the mitral valve. Cases 5 and 6 had mitral and aortic valve lesions. The remaining 6 patients had pure aortic valve incompetence. 
Patients were catheterized under light sedation with I50 mg. amylobarbitone. Retrograde aortography was performed by the Seldinger technique using PE 240 catheters, $125 \mathrm{~cm}$. long. The left atrium was catheterized by the method of Aldridge (1964) in most cases or, in a few, by a modification of the Ross technique (Verel, 1967). Introduction in all cases was by Seldinger wire. Wedged pulmonary capillary pressure measurements were made by a $125 \mathrm{~cm}$. 7 F Cournand catheter introduced through an antecubital vein incision. The Brockenbrough catheter (U.S.C.I.) used for the left atrial pressure measurements was connected to the pressure transducer by a length of recording tubing, making a total catheter length of $125 \mathrm{~cm}$.

Pressure was recorded on a Cambridge photographic recorder using Cambridge Instrument Company transducers and amplifiers. In all recordings the same pressure range was used for each transducer, zero being checked before and after each recording. The calibration of each transducer was checked against a mercury manometer. All recordings were made without electronic or mechanical damping.

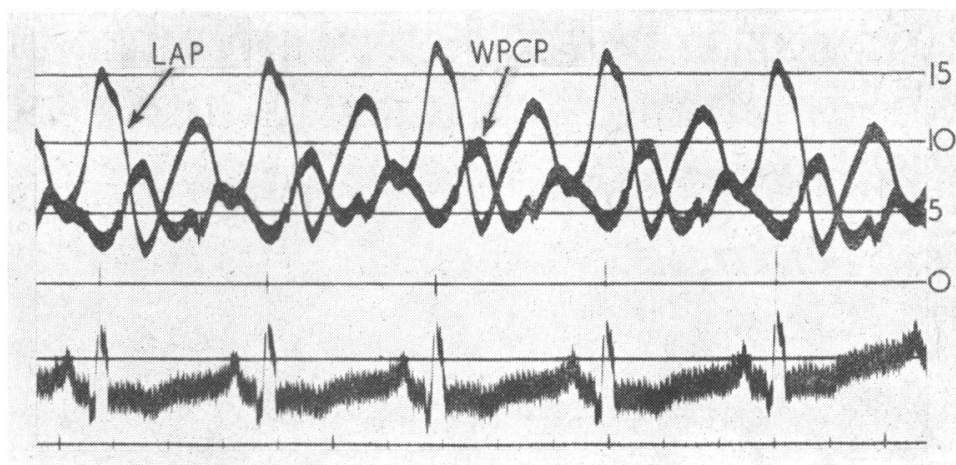

FIG. I Simultaneous recording of left atrial pressure by transseptal catheter and wedged pulmonary capillary pressure by Cournand catheter. The wedged pulmonary capillary pressure closely resembles the left atrial pressure, but is delayed and slightly damped.

TABLE Results of catheterization in 12 patients

\begin{tabular}{|c|c|c|c|c|c|c|c|c|c|c|c|c|}
\hline \multirow[b]{2}{*}{$\begin{array}{l}\text { Case } \\
\text { No. }\end{array}$} & \multirow[b]{2}{*}{$\begin{array}{l}\text { Age } \\
(y r .)\end{array}$} & \multirow[b]{2}{*}{ Diagnosis } & \multicolumn{7}{|c|}{ Pressures (mm. $\mathrm{Hg}$ ) } & \multirow[b]{2}{*}{$\begin{array}{l}\text { End-diast. } \\
\text { gradient }{ }^{\star}\end{array}$} & \multirow[b]{2}{*}{$\begin{array}{l}\text { Time } \\
\text { lag } \dagger \\
(\mathrm{sec} .)\end{array}$} & \multirow[b]{2}{*}{ Rhythm } \\
\hline & & & $\begin{array}{l}\text { Rt. } \\
\text { atrium }\end{array}$ & $\begin{array}{l}\text { Rt. } \\
\text { ventricle }\end{array}$ & $\begin{array}{l}\text { Pulm. } \\
\text { artery }\end{array}$ & $\begin{array}{l}\text { Wedged } \\
\text { pulm. } \\
\text { capillary }\end{array}$ & $\begin{array}{l}\text { Lt. } \\
\text { atrium }\end{array}$ & $\begin{array}{l}\text { Lt. } \\
\text { ventricle }\end{array}$ & Aorta & & & \\
\hline $\mathbf{I}$ & 34 & $\begin{array}{l}\text { Mitral stenosis } \\
\text { and incompetence }\end{array}$ & $5 /-2$ & $30 / 0$ & $30 / 15$ & $21 / 15$ & $22 / 12$ & $100 / 0$ & $100 / 55$ & - & 0.06 & $\begin{array}{l}\text { Sinus } \\
\text { rhythm }\end{array}$ \\
\hline 2 & 40 & $\begin{array}{l}\text { Mitral stenosis } \\
\text { and incompetence }\end{array}$ & $8 / 3$ & $50 / 5$ & $50 / 30$ & $18 / 10$ & $22 / 6$ & $150 / 10$ & $150 / 80$ & - & 0.06 & $\begin{array}{l}\text { Sinus } \\
\text { rhythm }\end{array}$ \\
\hline 3 & 49 & Mitral stenosis & $7 / 3$ & $30 / 3$ & $30 / 15$ & $15 / 10$ & $38 / 17$ & $100 / 6$ & $100 / 60$ & - & 0.14 & $\begin{array}{l}\text { Mitral } \\
\text { fibril- } \\
\text { lation }\end{array}$ \\
\hline 4 & 48 & Mitral stenosis & $12 / 5$ & $50 / 5$ & $50 / 30$ & $25 / 15$ & $50 / 20$ & $120 / 0$ & $120 / 80$ & - & 0.12 & $\begin{array}{l}\text { Atrial } \\
\text { fibril- } \\
\text { lation }\end{array}$ \\
\hline 5 & 51 & $\begin{array}{l}\text { Aortic and mitral } \\
\text { incompetence }+ \\
\text { mitral stenosis }\end{array}$ & $6 /-2$ & $23 / 0$ & $23 / 5$ & $15 / 12$ & $20 / 7$ & $160 / 0$ & $160 / 80$ & - & 0.12 & $\begin{array}{l}\text { Sinus } \\
\text { rhythm }\end{array}$ \\
\hline 6 & 41 & $\begin{array}{l}\text { Aortic incom- } \\
\text { petence (aortic } \\
\text { stenosis) (mitral } \\
\text { incompetence) }\end{array}$ & $7 / 2$ & $45 / 0$ & $45 / 25$ & $20 / 12$ & $25 / 10$ & $120 / 5$ & $100 / 50$ & 3 & 0.14 & $\begin{array}{l}\text { Atrial } \\
\text { fibril- } \\
\text { lation }\end{array}$ \\
\hline 7 & 33 & $\begin{array}{l}\text { Aortic } \\
\text { incompetence }\end{array}$ & $8 / 0$ & $25 / 0$ & $25 / 10$ & $12 / 5$ & $20 / 5$ & $120 / 5$ & $120 / 30$ & 8 & 0.12 & $\begin{array}{l}\text { Sinus } \\
\text { rhythm }\end{array}$ \\
\hline 8 & 45 & $\begin{array}{l}\text { Aortic } \\
\text { incompetence }\end{array}$ & $10 / 3$ & $20 / 3$ & $20 / 10$ & $15 / 10$ & $15 / 7$ & $120 / 0$ & $120 / 80$ & 5 & 0.12 & $\begin{array}{l}\text { Sinus } \\
\text { rhythm }\end{array}$ \\
\hline 9 & 59 & $\begin{array}{l}\text { Aortic } \\
\text { incompetence }\end{array}$ & $15 / 10$ & $80 / 10$ & $80 / 40$ & $60 / 30$ & $60 / 20$ & $160 / 20$ & $160 / 60$ & 5 & 0.14 & $\begin{array}{l}\text { Sinus } \\
\text { rhythm }\end{array}$ \\
\hline 10 & 42 & $\begin{array}{l}\text { Aortic } \\
\text { incompetence }\end{array}$ & $5 / 0$ & $20 / 0$ & $20 / 10$ & $18 / 8$ & $18 / 8$ & $110 / 20$ & $160 / 40$ & 6 & 0.14 & $\begin{array}{l}\text { Sinus } \\
\text { rhythm }\end{array}$ \\
\hline I I & 46 & $\begin{array}{l}\text { Aortic } \\
\text { incompetence }\end{array}$ & $9 / 0$ & $25 / 0$ & $25 / 10$ & $12 / 5$ & $15 / 5$ & $120 / 5$ & $120 / 45$ & 3 & 0.14 & $\begin{array}{l}\text { Sinus } \\
\text { rhythm }\end{array}$ \\
\hline 12 & 34 & $\begin{array}{l}\text { Aortic } \\
\text { incompetence }\end{array}$ & $7 / 0$ & $20 / 0$ & $20 / 8$ & $7 / 5$ & $10 / 5$ & $115 / 0$ & $115 / 80$ & 0 & 0.08 & $\begin{array}{l}\text { Sinus } \\
\text { rhythm }\end{array}$ \\
\hline
\end{tabular}


The recording system was tested at each catheterization to confirm that there was no significant difference in the speed with which pressure changes were transmitted through the catheters. On most occasions this was done by recording pressure from the right ventricle simultaneously by the Cournand and Brockenbrough catheters, and from the left ventricle by the Brockenbrough and aortographic catheters. When this was not possible, the transmission time was measured from the $R$ wave of the electrocardiogram on a high speed recording of ventricle pressure. In most cases there was no measurable difference in the timing of the recordings as the photographic traces merged. In no case was the difference in timing as large as $0.04 \mathrm{sec}$.

\section{Results}

The results obtained are shown in the Table.

In every case a simultaneous measurement of left atrial pressure and wedged pulmonary capillary pressure was obtained. The systolic and diastolic pressures corresponded closely in most cases. Where differences occurred they were consistently due to damping of the wedged pulmonary capillary pressure trace leading to a lower systolic pressure, higher diastolic pressure, or both (Luchsinger, Seipp, and Patel, 1962). The largest errors were encountered in 2 patients with pure mitral stenosis (Cases 3 and 4 , see the Table).

In all cases the wedged pulmonary capillary pressure trace lagged behind the recording of left atrial pressure by an interval which ranged from 0.06 to $0.14 \mathrm{sec}$. (Fig. I and the Table). This delay in transmission presumably represents the time taken for the pressure wave generated in the left atrium to pass through the pulmonary veins and capillary bed. The variability in this time lag is unexplained. It is not related to the level of pressure recorded, nor to the age or size of the patient. It is possibly significant that the shortest transmission times of $0.06 \mathrm{sec}$. were found in 2 patients suffering from mitral incompetence without aortic valve disease (Cases I and 2) but a time of 0.08 sec. was found in Case 12 who suffered from pure aortic incompetence.

The simultaneous recordings of left ventricular pressure and wedged pulmonary capillary pressure in the group of patients without mitral stenosis revealed an end-diastolic gradient in 6 patients (Cases 6-II, Fig. 2 and 3). All were suffering from aortic incompetence of moderate to severe degree. One patient (Case 9) was in severe right and left ventricular failure at the time of catheterization, remaining in this state with little change until successful operation relieved the situation. In one other patient (Case I2)

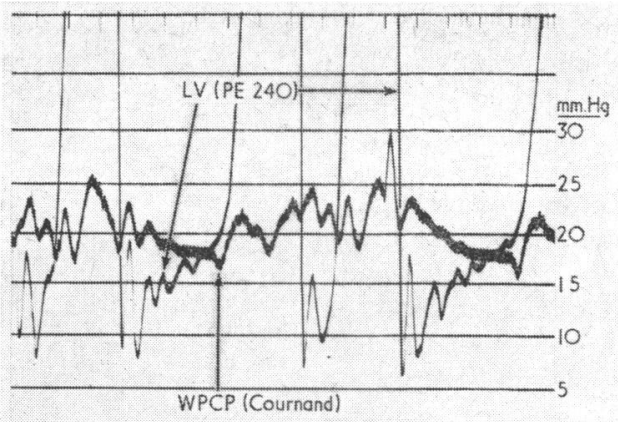

FIG. 2 Simultaneous tracing of the left ventricular pressure and wedged pulmonary capillary pressure. The record shows an end-diastolic gradient of about $5 \mathrm{~mm}$. $\mathrm{Hg}$ between the left atrium and left ventricle (Case II).

with a mild aortic valve leak the transmission time was short $(0.08 \mathrm{sec}$.), and in this case left ventricular pressure and wedged pulmonary capillary pressure tracings revealed no gradient (Fig. 4).

The direct left atrial pressure tracings were then compared with the left ventricular records. In Cases 6-I I the end-diastolic pressure in the left atrium was found to equal or exceed the end-diastolic ventricular pressure in every case (Fig. 5). The gradient shown by the wedged pulmonary capillary pressure measurement was thus shown to be

FIG. 3 Simultaneous tracing of the left ventricular pressure and wedged pulmonary capillary pressure from a patient in heart failure. An end-diastolic gradient of 3-5 mm. Hg is shown (Case 9).
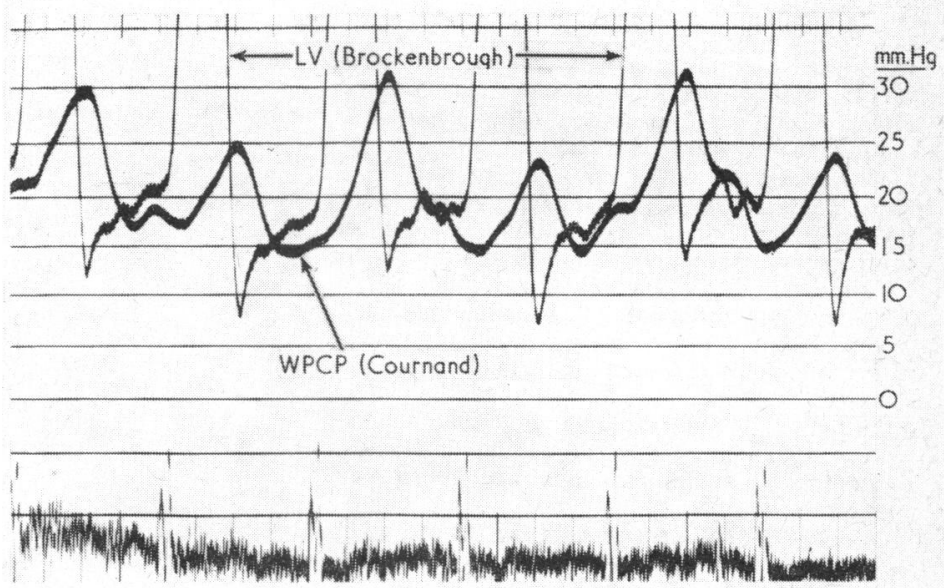
an artefact due to the time taken for the pulse wave to pass from the left atrium to the pulmonary capillaries.

\section{Discussion}

The delay between the events occurring in the left atrium and the corresponding pressure changes recorded in the pulmonary wedge position is of considerable importance. When related to the happenings in the left ventricle it may be long enough to produce an apparent end-diastolic gradient. In our cases this gradient was due primarily to displacement of the ' $a$ ' wave from the end of ventricular diastole to the beginning of ventricular systole. As a result, the recorded ventricular end-diastolic pressure corresponded to the phase of atrial pressure preceding ventricular systole. In addition, the reduction in the height of the ' $a$ ' wave on the wedged pulmonary capillary pressure tracing in some cases increased the apparent left atrial-left ventricular gradient. The delay in transmission along the pulmonary veins which was recorded in these patients ranged from 0.06 to $0.14 \mathrm{sec}$. None was a normal subject, but it is likely that the normal delay lies in the range of 0.12 to $0.14 \mathrm{sec}$. as most of the patients with pure aortic incompetence and normal left atrial function had transmission times of this order. There may be more than one factor responsible for the shorter times found in three patients (Cases I, 2, and 12). Two had considerable mitral incompetence without aortic valve disease. In these cases the reflux of blood from the atrium into the pulmonary veins may have shortened the transmission time.

\section{References}

Aldridge, H. E. (1964). Transseptal left heart catheterization without needle puncture of the interatrial septum. American fournal of Cardiology, 13, 239.

Colvez, P., Alhomme, P., Samson, M., and Guedon, J. (1959). La pression de remplissage du ventricule gauche dans les grandes insuffisances aortiques. Ses relations avec l'allongement de la conduction auriculo-ventriculaire. Archives des Maladies du Coeur et des Vaisseaux, 52, 1369.

Lochaya, S., Igarashi, M., and Shaffer, A. B. (1967). Late diastolic mitral regurgitation secondary to aortic regurgitation: its relationship to the Austin Flint murmur. American Heart fournal, 74, 16I.

Luchsinger, P. C., Seipp, H. W., Jr., and Patel, D. J. (1962). Relationship of pulmonary artery-wedge pressure to left atrial pressure in man. Circulation Research, II, 315.

Oliver, G. C., Jr., Gazetopoulos, N., and Deuchar, D. C. (1967). Reversed mitral diastolic gradient in aortic incompetence. British Heart fournal, 29, 239.

Verel, D. (1967). Catheterization of the left atrium by Ross needle and Seldinger wire techniques. British Heart fournal, 29, 380.

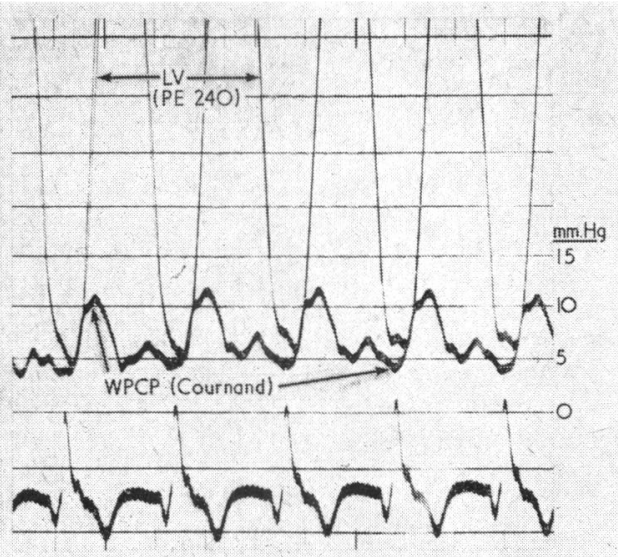

FIG. 4 Simultaneous left ventricular and wedged pulmonary capillary pressure tracing showing no end-diastolic gradient (Case 12).

- , and Taylor, D. G. (1967). Assessment of aortic valve stenosis by left ventricular puncture and left atrial catheterization. In Proceedings of the British Cardiac Society. British Heart fournal, 29, 633.

Welch, G. H., Jr., Braunwald, E., and Sarnoff, S. J. (1957). Hemodynamic effects of quantitatively varied experimental aortic regurgitation. Circulation Research, 5, 546.

Wigle, E. D., and Labrosse, C. J. (1965). Sudden severe aortic insufficiency. Circulation, 32, 708.

Wright, J. L., Toscano-Barboza, E., and Brandenburg, R. O. (1956). Left ventricular and aortic pressure pulses in aortic valvular disease. Proceedings of the Staff Meetings of the Mayo Clinic, 31, 120.

FIG. 5 Simultaneous left ventricular and left atrial pressure tracing from Case II. The end-diastolic gradient seen in Fig. 2 is an artefact due to the displacement and damping of the left atrial pressure in the wedged pulmonary capillary pressure record.

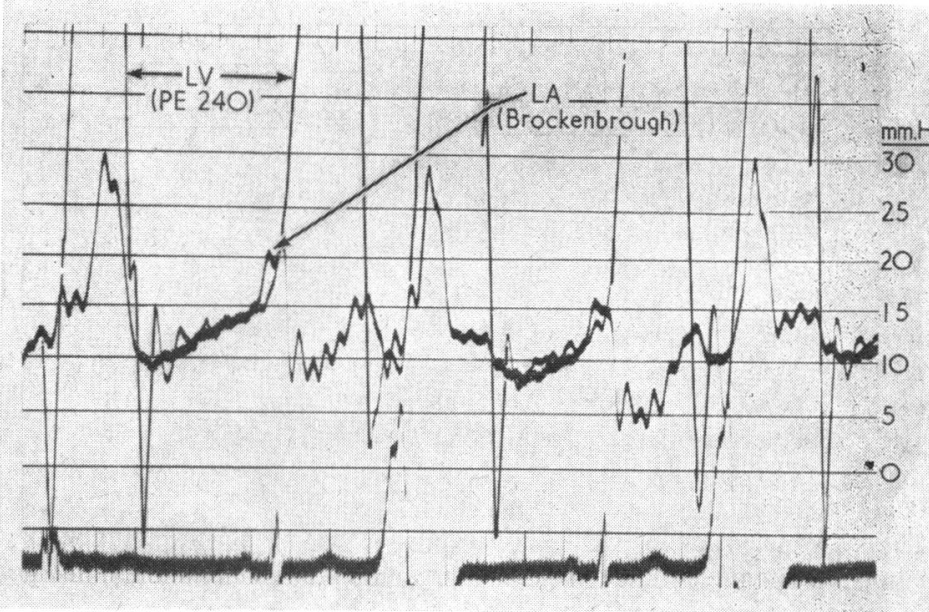

